\title{
Prediction of neuroticism based on attachment styles and early maladaptive schemas in clients of counseling centers in the City of Qom
}

\author{
Marzie Motaghian ${ }^{1}$, Sohrab Abdi Zarrin ${ }^{2}$ \\ 1-M.A, Department of Clinical Psychology, Islamic Azad University (Arak Branch), Arak, Iran (Corresponding \\ Author). $\quad$ E-mail: M-motaghian1989@yahoo.com \\ 2-Assistance professor, Department of Educational Sciences, University of Qom, Qom, Iran.
}

Received: 30/08/2019

Accepted: 24/11/2019

\begin{abstract}
Introduction: Neuroticism is defined as a general tendency to experience negative feelings. This factor is very important in psychology to predict of people's behavior.

Aim: The peresent study aimed at Predicting neuroticism based on attachment styles and early maladaptive schemas in clients of counseling centers in the City of Qom.

Method: This is a descriptive correlational study. The statistical population included all patients of counseling centers in Qom in 1395. A sample of 77 women and 50 men were randomly selected. Measurement tools included NEO Personality Inventory (NEO long form, NEO-PI-R), the Young Schema Questionnaire (long-form third edition of 232 questions) and Adult Attachment Inventory (AAI). To analyze the data, Pearson correlation coefficient and multiple regression were used.
\end{abstract}

Results: The results showed that the entire early maladaptive schemas and all three attachment styles (secure, avoidant, ambivalent) could significantly predict neuroticism of clients of counseling centers $(\mathrm{P}<0.05),(\mathrm{P}<0.01)$. Although all early maladaptive schemas and all three attachment was negatively correlated with neuroticism, and also three schmas namely abandonment/instability, insufficient self-control/ self-discipline, and negativity/ pessimism and two attachment styles that are secure and ambivalent predicted neuroticism more accurately.

Conclusion: Results revealed that the simultaneous role of attachment styles and early maladaptive schemas is significant in the Prediction of neuroticism. They imply that in counseling sessions with patients who suffer from neuroticisim, the counsellor must take into consideration the early maladaptive schemas and attachment styles.

Keywords: Neuroticism, Attachment styles, Early maladaptive schemas

\footnotetext{
How to cite this article : Motaghian M, Abdi Zarrin S. Prediction of neuroticism based on attachment styles and early maladaptive schemas in clients of counseling centers in the City of Qom. Shenakht Journal of Psychology and Psychiatry. 2019; 6 (5): 118-128 .URL:
} http://shenakht.muk.ac.ir/article-1-718-fa.pdf

Copyright $\odot 2018$ the Author (s). Published by Kurdistan University of Medical Sciences. This is an open access article distributed under the terms of the Creative Commons Attribution-Non Commercial License 4.0 (CCBY-NC), where it is permissible to download, share, remix, transform, and buildup the work provided it is properly cited. The work cannot be used commercially without permission from the journal. 


\title{
يشى بينى روان رنجورى بر اساس سبك هاى دلبستكى و طرح واره هاى ناساز كار اوليه در مراجعين مراكز مشاوره شهر قم
}

\author{
مرضيه متقيان'، سهر اب عبدى زرين'

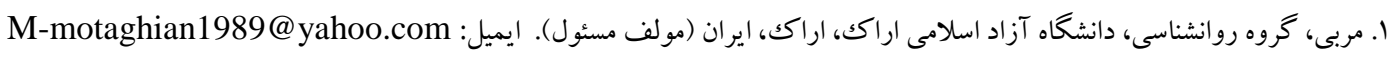 \\ r. استاديار، گروه علوم تربيتى، دانشكاه قم، قم، ايران.

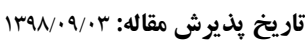

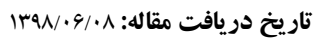

جكيده

مقدمه: روانرنجورى تمايل عمومى به تجربه عواطف منفى تعريف شده است و به عنوان يكى از خصيصههاى مهم در حوزه روانشناسى براى بيش بينى رفتار افراد مطرح است. هدف: يزوهش حاضر با هدف بيشينى روان رنجورى بر اساس سبككهاى دلبستخى و طرحوارههاى ناساز كار اوليه در مراجعين مراكز مشاوره شهر قم صورت كرفته است. روش: يزوهش حاضر توصيفى و از نوع همبستخى بود. جامعه آمارى شامل مراجعين مراكز مشاوره شهر قم در سال هوسا بود.

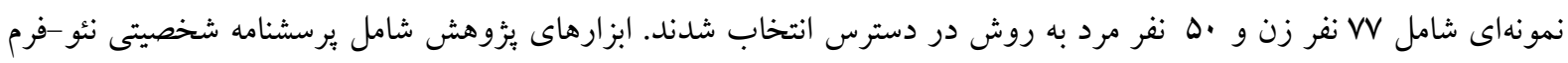

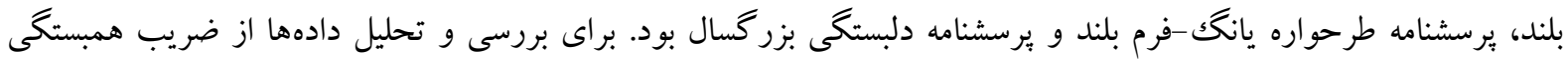
ويرسون و رگر سيون جند گانه استفاده شد.

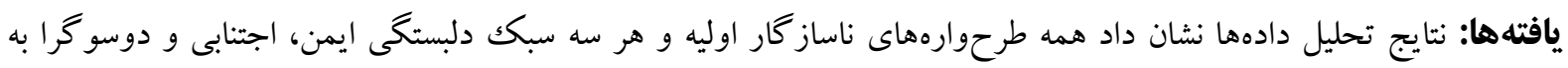

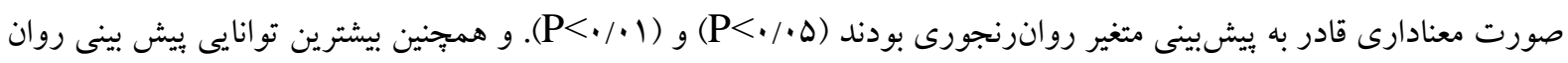

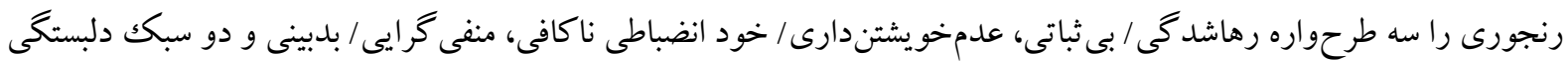
ايمن و دوسو خرا داشتند. نتيجه گيرى: بر اساس يافتهاى يُزوهش، نقش همزمان سبككهاى دلبستخى و طرحوارههاى ناساز كار اوليه در ييش بينى روان

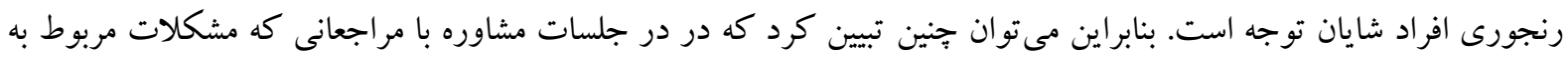

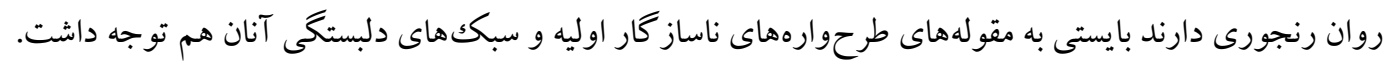
كليد وازهها: روان رنجورى، سبككهاى دلبستخى، طرحوارههاى ناساز كار اوليه 
عمدتاً در نتيجه تجارب ناكوار دوران كودكى شكل مقدمه

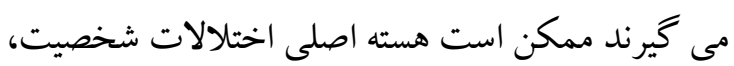
مشكلات منش شناختى خفيف تر و بسيارى از

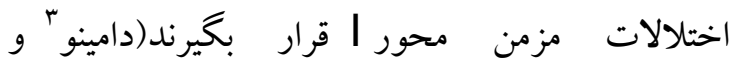

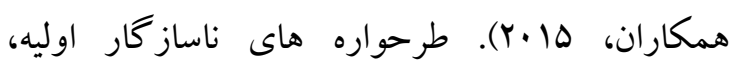
خودشان را از طريق تحريف هاى شناختى، الكوهاى زندگى خود آسيب رسان نشان مى دهند و به طور مستقيم و غيرمستقيم منجر به بريشانى و مشكلات

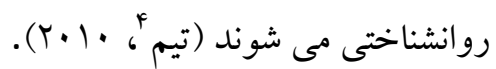
دلبستگى ايمن به ديخران، خود گردانى، آزادى در بيان

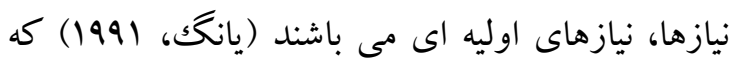

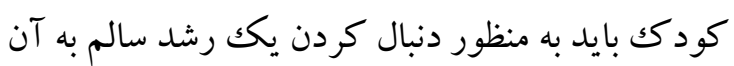
ها دست يابد (تيم، · · ·r). وقتى مراقبان، دستيابى به يكك يا تعداد بيشترى از اين نيازها را مشكل سازند،

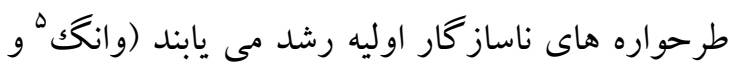

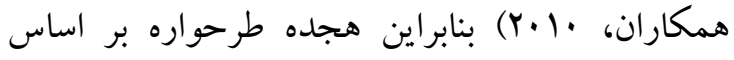
نيازهاى هيجانى ارضا نشده تقسيم مى شوند كه آن ها را حوزه هاى طرحواره مى نامند. حوزه اول: طرد و بريدكى (عدم ارضاى نياز به ثبات، امنيت، محبت، عشق و تعلق خاطر) و طرحواره هاى مبتنى بر آن

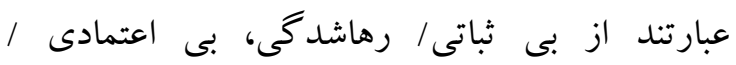

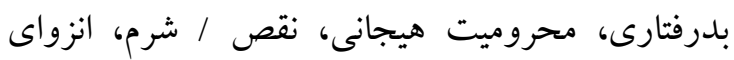

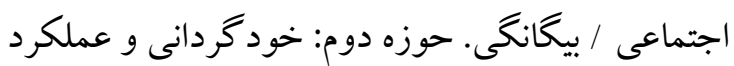
مختل (افراط وتفريط در حمايت از كودك و و كاهش اعتمادبه نفس كود كك) و طرحواره هاى مرتبط عبارتند از وابستكى / بيكفايتى، آسيب بذيرى نسبت به ضرر يا

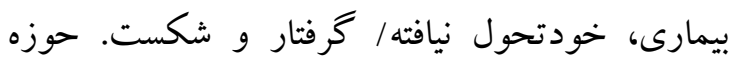
سوم: محدوديت هاى مختل (مشكل در ارتباط با احترام به حقوق ديخران، همكارى كردن، متعهد بودن يا مختل دستيابى به اهداف بلند مدت) و طرحواره هاى مرتبط

\footnotetext{
3- Damiano

4- Thimm

5. Wang
}

1. McCrae \& Costa
2- Young \& Klosko

تمايل عمومى به تجربه عو اطف منفى جون ترس، غم، اضطراب، عصبانيت، احساس گناه و نفرت مجموعه حيطه روان رنجورى را تشكيل مى دهد. هر جند روان رنجورى جيزى بيشتر از آمادگى براى ناراحتى هاى

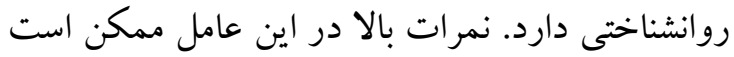
نشانه احتمال بالا براى ابتلا به برخى از انواع مشكلات

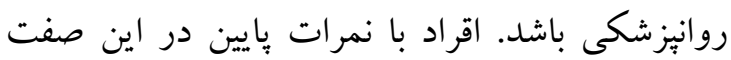

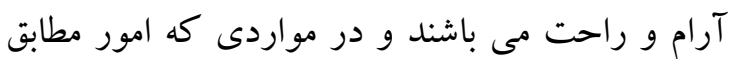
خواست آن ها بيش نمى رود، ستيزه جويى نمى

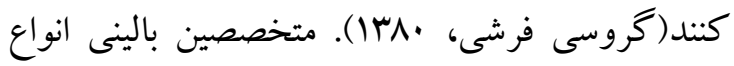

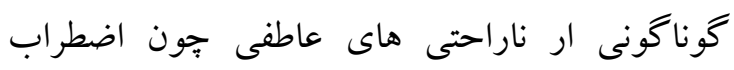

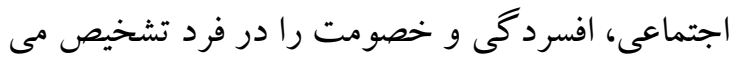
دهند، اما مطالعات بى شمار نشان مى دهد افرادى كه مستعد يكى از اين وضعيت هاى عاطفى هستند احتمالا

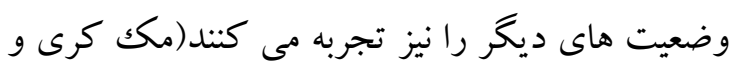

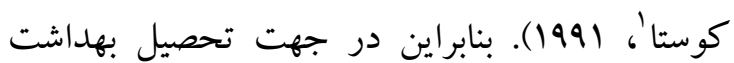
روان جامعه، لازم است عواملى كه مى توانند روان رنجورى را ييش بينى كنند، تشخيص داده و در جهت كاهش اين عوامل و كم كردن عواطف و هيجانات منفى و آسيب هاى ناشى از آن، اقدامات بايه ایى و يشيخير انه به عمل آورد. يكى از عواملى كه مى توان به بررسى بيش بودن آورد آن در روان رنجورى برداخت، طرحواره هاى ناساز گار اوليه

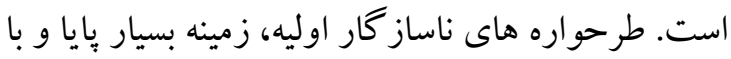
دوام بين فردى و بسيار ناكارامدى است كه در جريان

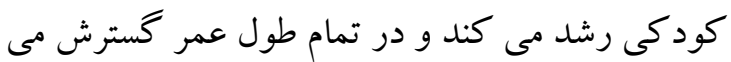
يابد و از اين رو، افراد را در برابر اختلالات روانشناختى

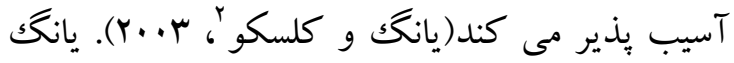
بيان مى كند برخى از طرحواره ها به ويزه آن ها كه 
اجتناب مى كنند. و بالاخره به كودكانى كه در غياب

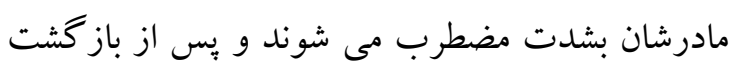

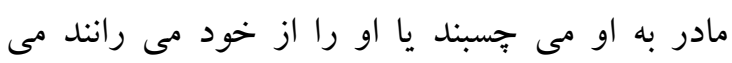

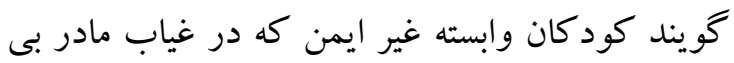

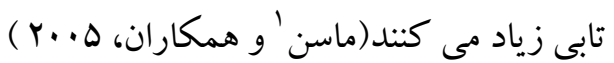
زارعى، بلداجى و حيدرى (سوبا) در بزّوهشى به

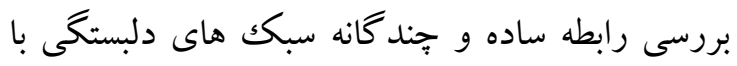
صفات ينج عامل شخصيت برداخت. نتايج تحليل

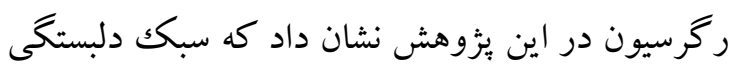
ايمن با صفت روان رنجورخويى رابطه منفى و سبك

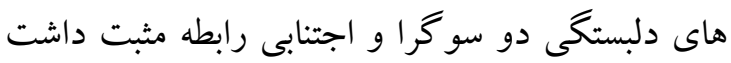

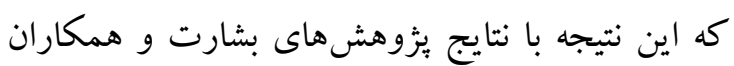

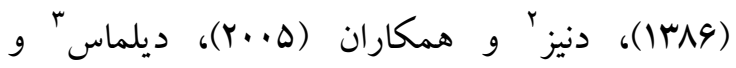

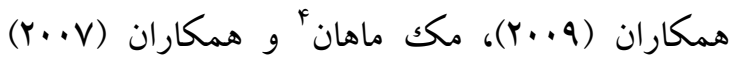

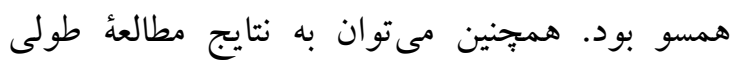

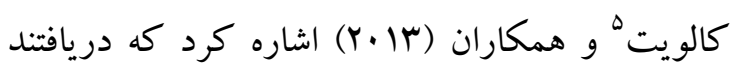
طرح وارههاى ناساز كار اوليه به بروز هراس اجتماعى منجر مىشود و اين مطالعه نشان مى دهد كه طرح

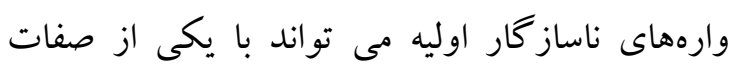

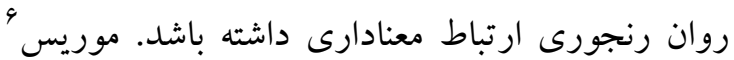
طى مطالعه اى گز ارش كرد كه تمامى طرحواره هاى

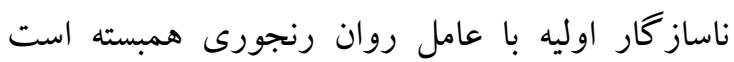

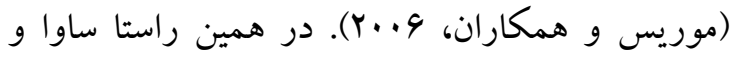

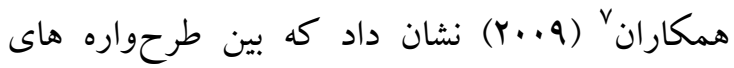
ناساز گار اوليه با روان رنجورى بالا رابطه معنادارى وجود داشت. علاوه بر اين، بهرامى زاده و همكاران

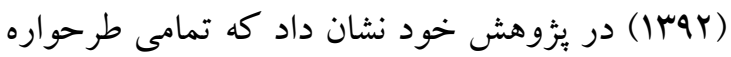
هاى ناساز گار اوليه با روان رنجورى به طور معنادارى

\footnotetext{
1- Mason

2- Deniz \& etal

3. Dilmaç \& etal

4- McMahon

5 - Calvete

6 - Muris

7. Sava
}

عبارتند از استحقاق / بزرگك منشى و خودكنتلى ناكافى. حوزه جهارم: ديخر جهت مندى (توجه بيش از حد به ديخران و عدم رسيدگى به ارضاى نيازهاى خود) و طرحواره هاى مرتبط عبارتند از اطاعت، ايثار و به وله

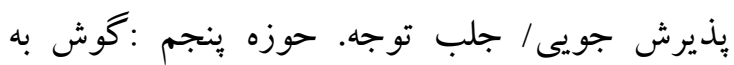

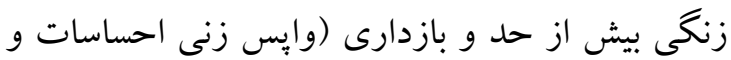

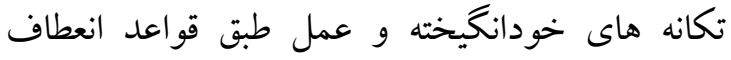
نايذير و درونى شده خود) و طرحواره هاى مبتنى بر آن عبارتند از منفى گرايى/ بدبينى، بازدارى هيجانى، معيارهاى سرسختانه / عيب جويى افراطى و تنبيه (1991) (يانخك، (199). طرحواره هاى ناساز كار اوليه بر روى عميق ترين

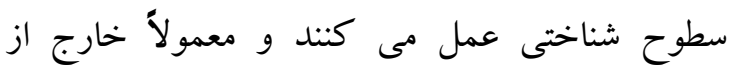
هشيارى هستند و افراد را از لحاظ روانشناختى در برابر

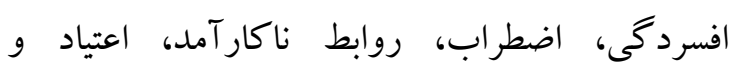

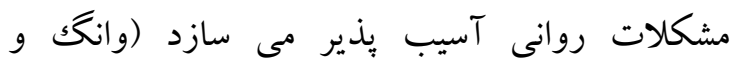

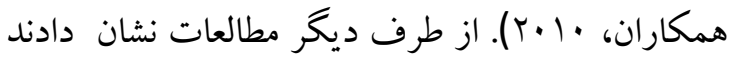
كه سبك هاى دلبستخى بر سازه هاى روانشناختى

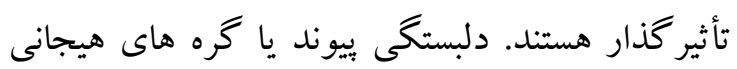
يايدار بين دو فرد است به طورى كه يكى از طرفين كوشش مى كند نزديكى يا مجاورت با موضوع دلبستگى را حفظ نموده تا مطمئن شود كه ارتباط ادامه

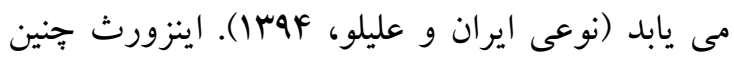
نتيجه گيرى كرد كه سه سبك عمده دلبستخى وجود

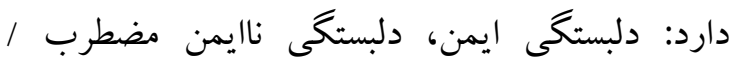

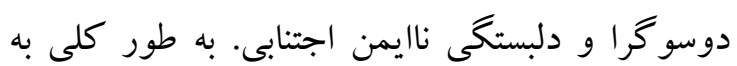

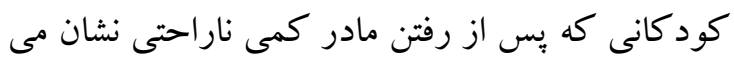

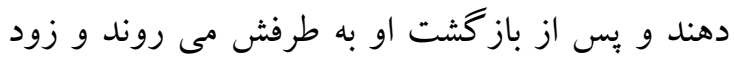

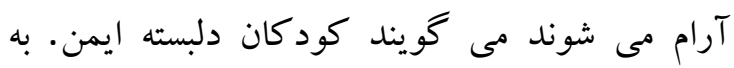
كودكانى كه از رفتن مادر شكايتى نمى كنند و به هنگام باز گشت با رضايت به بازى خود ادامه مى دهند مى گويند كود كان دلبسته غير ايمنى كه از مادر خود 
همبسته است. رضايى و همكاران(YMMا) نشان دادند كه بين طرحواره هاى ناساز كار اوليه با روان رنجورى در اين إيزوهش از سه يُرسنامه شخصيتى نئو- فرم بالا همبستكى مثبت معنادارى وجود دارد. بر اساس

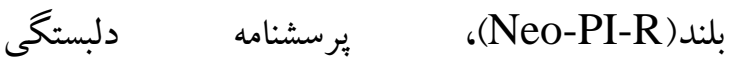
مطالب بيان شده، يزوهش حاضر با هدف بيش بينى بزر گسال(AAI) و برسشنامه طرحواره يانگك (فرم بلند - وير است سوم - بr سو سو الى) استفاده شد. يرسشنامه شخصيتى نئو (NEO-PI-R): اين برسشنامه ه روان رنجورى بر اساس سبك هاى دلبستگى و طرح

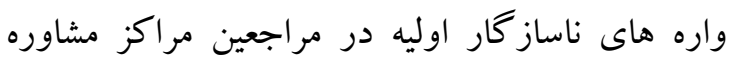

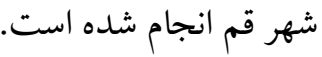
عامل اصلى شخصيت و 9 خصوصيت در هر عامل يا به

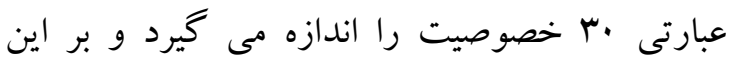

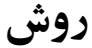
اساس ارزيابى جامعى از شخصيت را ارائه مى دهد.

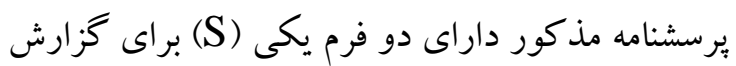
هاى شخصى است و شامل · · سوال بنج درجه ایى از

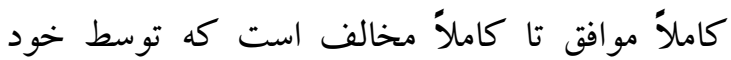
آزمودنى درجه بندى مى شود و متناسب مردان و زنان در تمام سنين است . و ديخرى فرم (R) يا تجديد نظر مورد شده نام دارد و بر اساس درجه بندى هاى مشاهده گر است . اين فرم نيز داراى همان ·FF سوال بوده با اين تفاوت كه با ضمير سوم شخص شروع مى شود .فرم هم مى تواند به طور مستقل براى ارزيابى شخصيت به كار رود و هم به عنوان مكملى براى گز ارش هاى شخصى فرم (S) و يا روايى آن مورد استفاده قرار

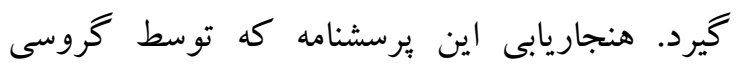
فرشى روى نمونه اى با حجم ب... نفر از بين بين دانشجويان دانشگاه هاى تبريز ، شيراز و دانشگاه هاى لهري علوم يزشكى اين دو شهر صورت كرفت، ضريب

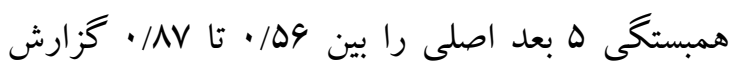
كرده است. ضرايب آلفاى كرونباخ در هر يكك از عوامل اصلى روان رنجورى، برون گرايى، باز بودن،

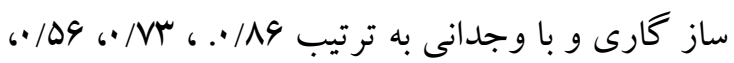
191/ و AV/· به دست آمد . جهت بررسى اعتبار محتوايى اين آزمون از همبستخى بين دو فرم گزارش

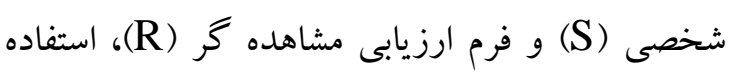


ناساز گارانه اوليه در ه حوزه مختلف طرح واره اى است ـ افراد خودشان را براساس اين كه كدام طرحواره ها وضعيت آنان را توصيف مى كند، بـر مبنـاى مقيـاس 9 درجـه اى ليكرت ارزيابى مى كنند. آلفاى كرونباخ در مورد 1) مقياس اين برسشنامه مطلوب و بين V9/• تا

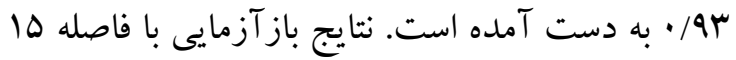

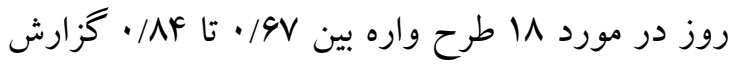
شده است. اين يرسشنامه از اعتبار صورى مطلوبى برخوردار است(فتى و همكاران، MNM ).

يافته ها اطلاعات جمعيت شناختى بيان مى كند كه لنه و •ها نفر مرد شركت كننده در اين بثزوهش در دامنه

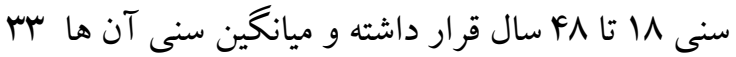
است. حداقل مدرك تحصيلى سيكل و حداكثر كارشناسى ارشد داشتند. همجنين در اين بثزوهش كه با هدف ييش بينى روان رنجورى بر اساس سبك هاى

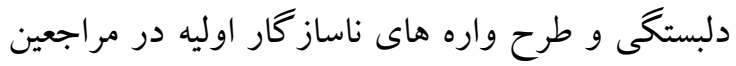
مراكز مشاوره شهر قم صورت گرفت، در سطح آمار توصيفى از ميانگين و انحراف معيار و در سطح آمار

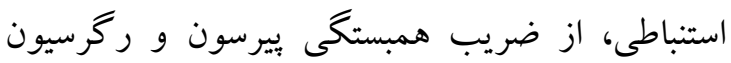

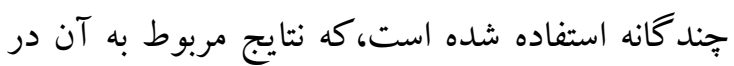
جداول زير ارائه شده است.
شد، كه حداكثر همبستگى به ميزان 194. در عامل برون گرايى و حداقل آن به ميزان هـ/ ساز گارى بود (9). يرسشنامه دلبستغى بزركسال (AAI): اين مقياس كه با با استفاده از مواد آزمون دلبستگى هازن و شيور (19AV) و در مورد دانشجويان دانشگاه تهران هنجاريابى شده است، يكك برسشنامه دو قسمتى مى باشد. در قسمت

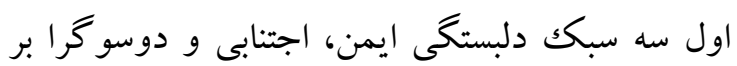
حسب اب سوال در مقياس ه درجه ای ليكرت

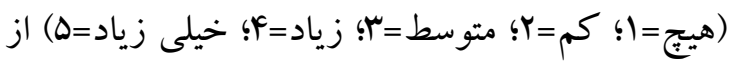
هم متمايز مى شوند. ضريب آلفاى كرونباخ برسش هاى هر يكك از زير مقياس هاى ايمن، اجتنابى و هون هرئ

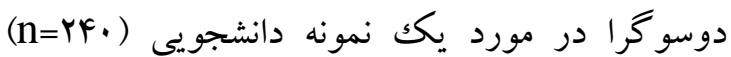
براى كل آزمودنى ها به ترتيب م⿸ باشد. ضريب همبستكى بين نمره هاى آزمودنى هاى برى دختر و بسر به ترتيب ه内/• و AV/ • بود. ضريب بايايى باز آزمايى مقياس دلبستخى بزر گسالان براى يكك نمونه

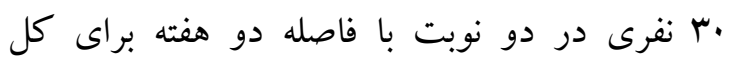

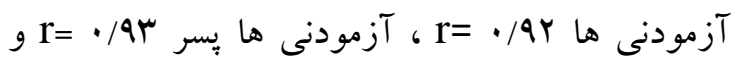

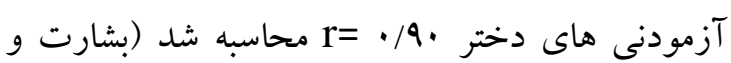

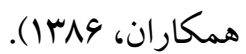

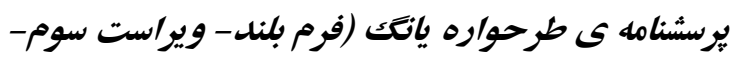

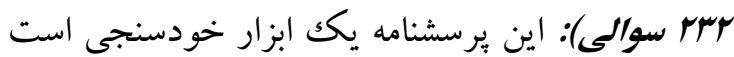

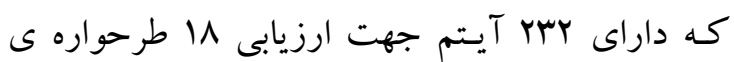

\begin{tabular}{|c|c|c|c|c|}
\hline انحراف استاندارد & ميانغين & روانرنجورى & طرحوارههاى ناساز تار اوليه & رديف \\
\hline $1 Y / 94$ & $r 4 / .0$ & $\cdot / F V \mid * *$ & محروميت عاطفى & 1 \\
\hline$|\Delta / \mu|$ & $F I / V F$ & 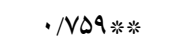 & رها شدگى / بى ثباتى & $r$ \\
\hline $\mid F / \wedge \Delta$ & $\mathrm{rq} / \Lambda$. & $\cdot / \Delta \wedge 9_{*} * * *$ & بى اعتمادى/بد رفتارى & $r$ \\
\hline $1 \cdot / 4 r$ & $r \cdot / \cdot 1$ & .1911 \% & انزواى اجتماعى / بيكانكى & p \\
\hline$I Y / M$ & rQ/AD & $\cdot 19 \cdot r^{*}$ 米 & نقص و شرم & $\Delta$ \\
\hline $1 . / 19$ & $r \cdot / F r$ & $\cdot 19 \cdot 1$ 类䉼 & شكست & 9 \\
\hline $9 / 94$ & $r \wedge / \backslash \Lambda$ & . $19 \mathrm{TV}$ 米米 & وابستكى /بى كفايتى & $\checkmark$ \\
\hline
\end{tabular}




\begin{tabular}{|c|c|c|c|c|}
\hline $1 . / 1 \mathrm{~V}$ & $r \mu / .9$ & $\cdot / 01 \wedge$ 米莎 & آسيب يذيرى نسبت به خود & $\wedge$ \\
\hline $9 / \Gamma \cdot$ & $r \cdot / 91$ & $\cdot / F V \mid$ 米米 & خود تحول نيافته / كرفتار & 9 \\
\hline $9 / 9 \wedge$ & $r r / 9 Q$ & $\cdot 1990$ 米粠 & اطاعت & $1 \cdot$ \\
\hline IN/VA & $0 \cdot / 9 \mathrm{~V}$ & $\cdot / T Y F_{*} * *$ & ايثار & 11 \\
\hline$\Lambda / F 1$ & $19 / V Y$ & $\cdot 19 \mathrm{~V} \mathrm{~V}^{2}$ 米 & بازدارى هيجانى & ir \\
\hline ID/Ar & FN/99 & $\cdot / 019 \% *$ & معيارهاى سر سختانه & ir \\
\hline $9 / \vee 9$ & $r V / A l$ & $\cdot / 011$ 米米 & استحقاق / بزرگك منشى & if \\
\hline Ir/AD & $r N / \cdot r$ & $\cdot$ VIf & عدم خويشتن دارى خود & 10 \\
\hline $\mid r / 9 Y$ & $r F / 90$ & $\cdot / D F V^{*}{ }^{*}$ & يذيرش جويى / جلب توجه & 19 \\
\hline $1.19 \mathrm{~V}$ & $r \Delta / \cdot V$ & $\cdot 19 \Lambda \cdot * * * *$ & منفى گر ايى/ بدبينى & iv \\
\hline $11 / \Delta 9$ & $r \Delta / F q$ & $\cdot / \Delta 91$ 光粎 & تنييه & 11 \\
\hline
\end{tabular}

اوليه مثبت و معنىدار بود، اما كمترين ميزان همبستكى بين روانرنجورى و متغير ايثار است (r=•/TYF). بيشترين ميزان همبستكى بين متغير روانرنجورى و ولين

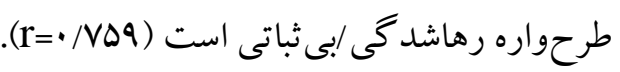

ضرايب همبستگى در جدول | نشان داد، متغير روانرنجورى با همه طرحوارههاى ناساز گار اوليه

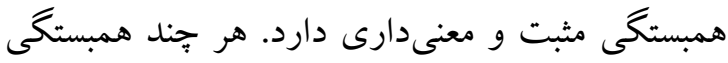
بين متغير روانرنجورى با همه طرحوارههاى ناساز گار

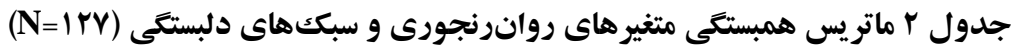

\begin{tabular}{|c|c|c|c|c|c|c|}
\hline$\varphi$ & $r$ & r & 1 & انحراف استاندارد & ميانكين & متغير هاى تحقيق \\
\hline & & & 1 & rq/VA & $\Lambda r / F V$ & روانرنجورى \\
\hline & & 1 & $-\cdot / F \Delta F_{\text {粠 }}$ & $F / \mu 1$ & $r q / 1 T$ & دلبستگى ايمن \\
\hline & 1 & $-\cdot 1910 \% *$ & $\cdot / \Delta 1 \Gamma_{*}$ & $F / \wedge)$ & $1 f / 9$. & دلبستگى اجتنابى \\
\hline 1 & $\cdot / Y Y F_{*}$ & $\cdot / \cdot F$ & $\cdot / 499 \%$ & $F / q F$ & $r F / T \Delta$ & دلبستغى دوسو كرا \\
\hline
\end{tabular}

جدول r نشان داد هر سه سبك دلبستخى ايمن، اجتنابى و دوسو گرا مى تواند متغير روان رنجورى را ييش بينى كند و بين اين دو متغير رابطه معنى دارى وجود دارد.

جدول r نتايج ركرسيون كام به كام روانر نجورى بر اساس طرحوارههاى ناساز كار اوليه و سبككهاى دلبستىى

\begin{tabular}{|c|c|c|c|c|c|c|c|c|c|}
\hline ضريب & ضر يب & معنادارى سطح & ضريب & ميانتين & دزاجه & مجرموع & تخنبع & متغير هاى ييشبين & كام \\
\hline \multirow[t]{2}{*}{$\cdot / \Delta V \Delta$} & $\cdot / V \Delta Q$ & $\cdot / \cdots$ & $199 / \mathrm{Fr}$ & $G F r \cdot r / M \Delta$ & 1 & GFT.r/TS & ركرسيون & 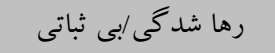 & 1 \\
\hline & & & & $r v q / \Delta \Delta$ & ird & FVFFF/YD & باقيمانده & & \\
\hline \multirow[t]{2}{*}{.1901} & $\cdot / \Lambda \cdot V$ & $\cdot 1 \cdots$ & IID/Ar & rqMar/Al & r & VYVAV/GY & رگر سيون & بى ثباتى و & $r$ \\
\hline & & & & MIF//9 & IYF & 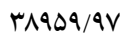 & باقيمانده & دارى خود & \\
\hline \multirow[t]{2}{*}{.1991} & ·|Ar| & $\cdot 1 \cdots$ & $91 / 01$ & YOVYF/I9 & $r$ & VVIVY/FA & ركرسيون & ل & $r$ \\
\hline & & & & r人l/l. & 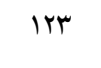 & rFovo/II & باقيمانده & منف & \\
\hline$\cdot / v \cdot V$ & $\cdot|A F|$ & $\cdot 1 \cdots$ & $V T / 9 V$ & IQVDG/Ar & F & $V Q \cdot r V / r$. & & رها شدكى /بى ثباتى و & p \\
\hline
\end{tabular}




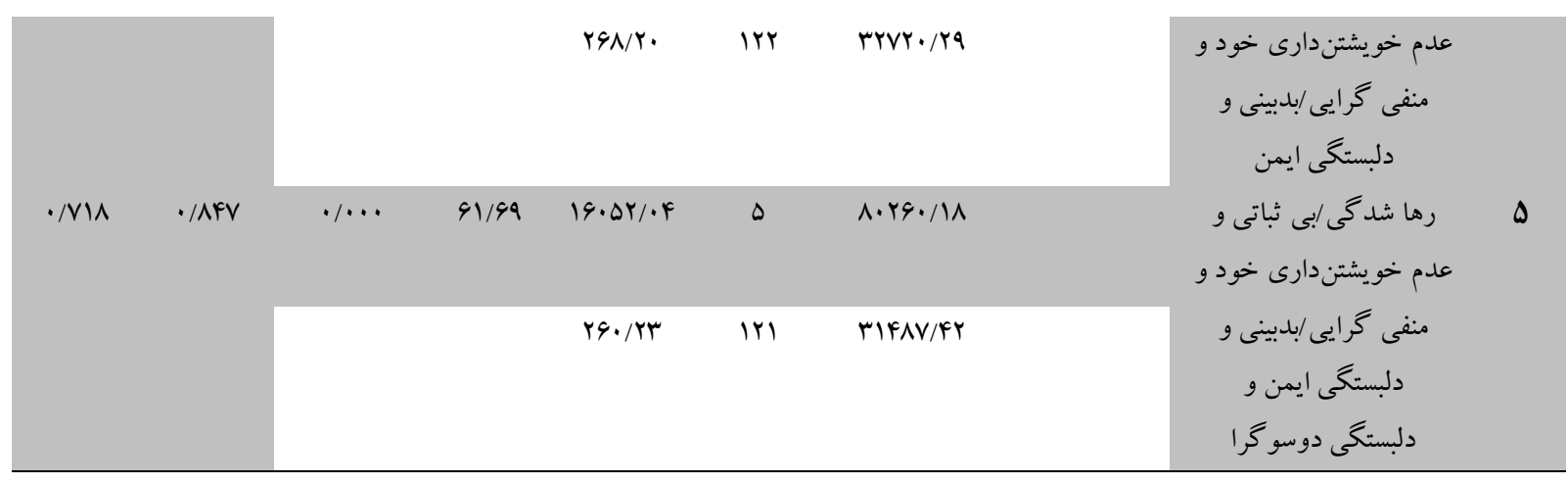

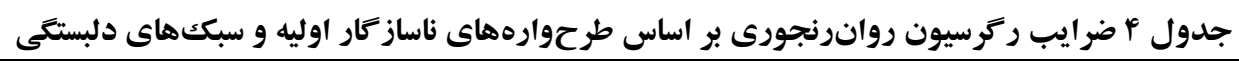

\begin{tabular}{|c|c|c|c|c|c|c|c|}
\hline \multicolumn{2}{|c|}{ شاخص هاى همخطى } & \multirow[t]{2}{*}{ سطح معنادارى } & \multirow[t]{2}{*}{ ضريب T } & \multirow[t]{2}{*}{ ضريب بتا } & \multirow[t]{2}{*}{ انحر اف معيار } & \multirow[t]{2}{*}{ ضريب B } & \multirow[t]{2}{*}{ متغير } \\
\hline VIF & تول & & & & & & \\
\hline & & $\cdot 1 \cdot \cdot 9$ & $r / 90$ & - & IT/V. & MT/99 & مقدار ثابت \\
\hline r/94 & $\cdot / M F$ & $\cdot / \cdot r$ & $r / 9 \Lambda$ & $\cdot / r \Delta$ & .119 & $\cdot / 4 \wedge$ & رها شدكى /بىثباتى \\
\hline $1 / A V$ & $\cdot / \Delta F$ & $\cdot / \cdots$ & $\Delta / \cdot r$ & $\cdot \pi$ & $\cdot / \mathrm{f}$ & $\cdot / N 1$ & عدم خويشتندارى \\
\hline 1/^9 & . /Qr & $\cdot / \cdot \cdot 1$ & r/FD & 每 & .119 & .194 & منفى گر ايى /بدينى \\
\hline $1 / \pi r$ & $\cdot / \mathrm{V} \Delta$ & $\cdot / \cdot r$ & $-r / \Lambda$ & $-\cdot / 1 \wedge$ & $\cdot / 49$ & $-1 / Y Y$ & دلبستغى ايمن \\
\hline $1 / 49$ & $.19 \mathrm{~V}$ & $\cdot / \cdot \mu 1$ & $r / M \Lambda$ & $\cdot / \pi$ & $\cdot / \pi \Delta$ & $\cdot / \mathrm{WV}$ & دلبستكى دوسوكرا \\
\hline
\end{tabular}

هاى ناساز گار اوليه در مراجعين مراكز مشاوره شهر قم بود. طبق يافته هاى اين يزوهش، بين طرح واره هاى

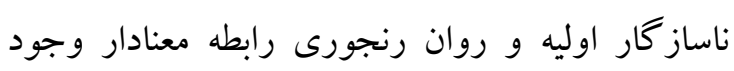

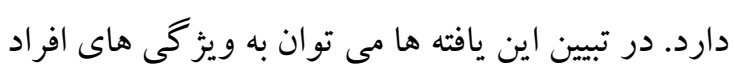

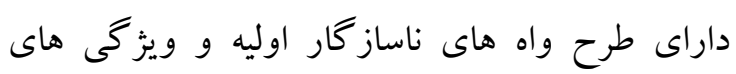
افرادى كه داراى روان رنجورى بالايى هستند، اشاره كرد. بخش عمده اى از استرس روان شناختى انسان به شيوه رويارويى وى با مشكلات بر مى گردد و طرح

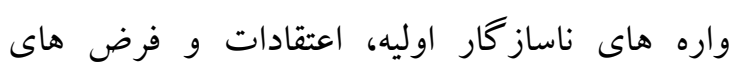
نادرستى هستند كه تفاسير، ادراكك ها، احساسات و واتو رفتارهاى فرد را تحت تاثير قرار مى دهند(يانگى، ادئل (1991). بر اساس تحليل هاى انجام شده، مهمترين عامل فردائ

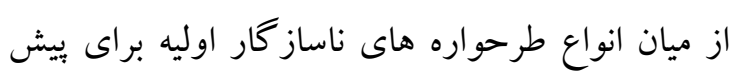

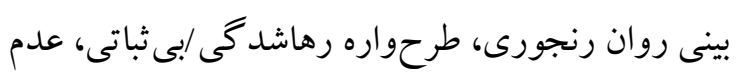

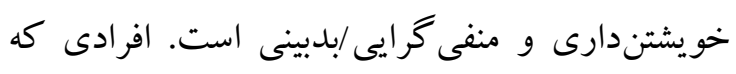

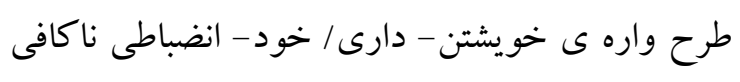
دارند، نمى توانند براى دستيابى به اهدافشان، خو يشتن -
جدول F بر اساس مدل رگرسيون خطى به روش گام به

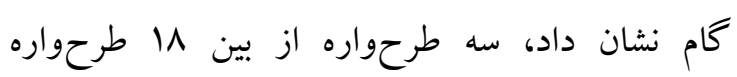
ناساز گار اوليه و دو سبكك دلبستخى ايمن و دوسو گرا

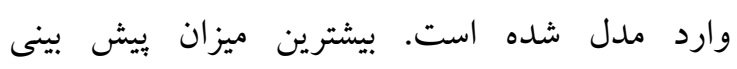
روانرنجورى با طرحواره عدم خويشتندارى است مدري (س//. رهاشدگى ابىثباتى از ضريب رگرسيون ساير متغيرها بيشتر است. ضريب رگرسيون دلبستخى دوسو گرا نيز مثبت است كه نشاندهنده قابليت بيش بينى روان رنجورى به وسيله اين متغير است؛ اما ضريب ركرسيون دلبستخى ايمن، منفى است كه نشان مىدهد اين سبك ونيله دلبستكى به صورت معكوس با روانرنجورى ارتباط

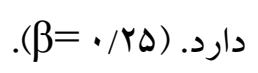

هدف از انجام يُزوهش حاضر بررسى بيش بينى روان رنجورى بر اساس سبك هاى دلبستگى و طرح واره 
مى كنند هميشه كارهاى شغلى، اقتصادى و بين فردى به طرز اسفناكى اشتباه از آب در مى آيند. اين بيماران از اشتباه كردن خيلى مى ترسند. اين نوع طرز تفكر به

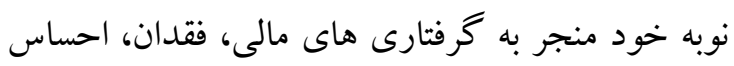

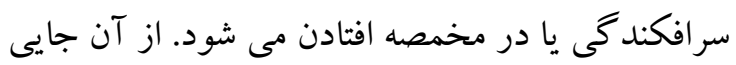
كه جنين بيمارانى، نتايج منفى احتمالى را اغراق آميز

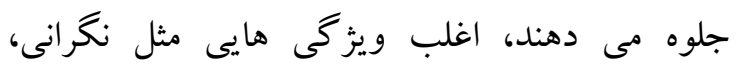
تشويق، گوش به زنكىى، غر زدن و و بلاتكليفى

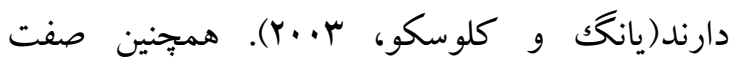
افسردگى در روان رنجورى تفاوت افراد سالم را در مر مركين

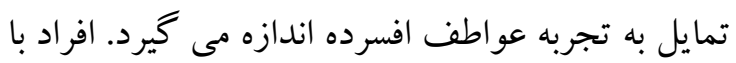

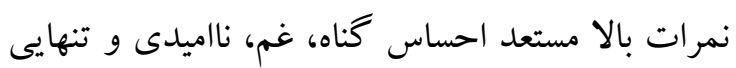
هستند. آن ها به راحتى مايوس مى شوند و اغلب

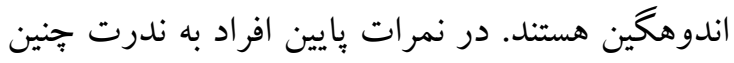

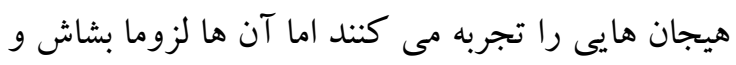

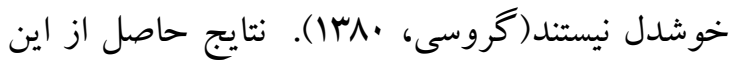
يثزوهش با نتايج حاصل از يزوهش هاى ديخر كه به طور مستقيم به بررسى رابطه بين طرح واره هاى ناساز كار اوليه و روان رنجورى توجه كرده اند، همانند

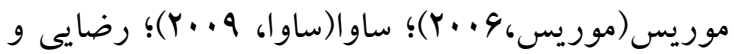

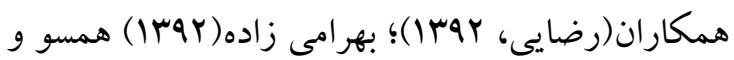
هماهنگك مى باشد. از طرف ديخر اصطلاح سيستم دلبستخى به سيستمى بـى تنظيم كننده اتلاف مى شود كه فرض مى شود اين سيستم در درون فرد وجود دارد(ماسن و همكاران،

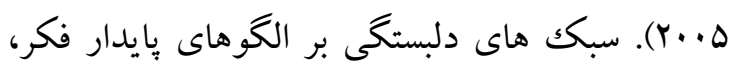
انخيزش، هيجان، كنترل هيجان، كنترل تكانه و عملكرد بين فردى تاثير مى گذارد و اين عواملى هستند كه در مر بيش بينى روان رنجورى نيز موثر هستند. روان رنجورى به منزله احساس نامنى روانشناختى در قلمرو روابط بين فردى است، احساسى كه سبك دلبستكى نايمن اساسا و در دوران نوزادى بر مبناى آن در جارجوب رابطه
دارى نشان دهند و ناكامى را به قدر كافى تحمل كنند. از سوى ديخر نمى تو انند ابراز هيجان ها و تكانه هايشان را كنترل كنند. در شكل هاى خفيف تر اين طرح واره،

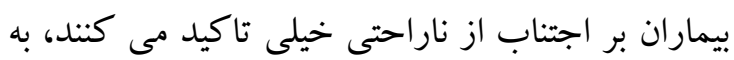
عنوان مثال سعى مى كنند در روابط بين فردى، تعارضى ايجاد نكنند و از يذيرفتن مسئوليت هاى بيشتر طفره مى

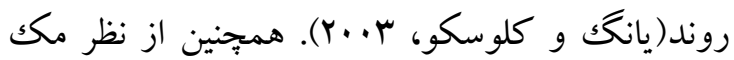
كرى و كاستا صفت شتابزدگى يا تكانشورى در روان رنجورى به ناتوانى در كنترل هوس ها، ميل ها و آرزوها مربوط مى شود. اين اميال به حدى قوى به نظر مى رسند كه فرد نمى تواند در جلوى آن ها مقاومت

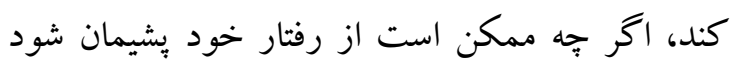
افراد در نمرات بِيين مقاومت در مقابل جنين وسوسه هايى را آسان مى دانند و تحمل بالايى در مقابل ناكامى تصى دارند(گروسى، ·^ها).در خصوص ارتباط طرحواره رهاشدگى و عامل روان رنجورى ميتوان گفت از نظر

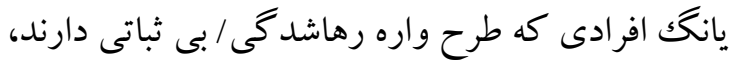
بى اعتمادى نسبت به دريافت محبت دارند و اعتقاد دارند روابطشان با افراد مهم زندگى ثباتى ندارد. همجنين بى ثباتى هيجانى و غير قابل بيش بينى بودن

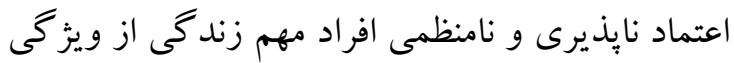
هايى است كه در زيربناى شكل گيرى طرح واره

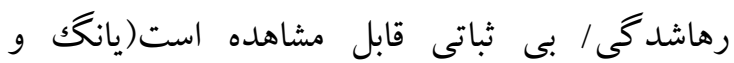

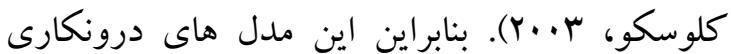
شده نايمن، گسترش يافته و ويز گیى هاى مرتبط با روان مدان رنجورى را ايجاد خواهد كرد. در تبيين طرح واره

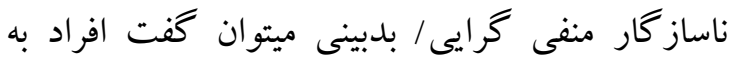
جنبه هاى منفى زندگى (مثل درد، مرگك، فقدان، نااميدى، تعارض و خيانت) خيلى توجه مى كنند، در لهر حالى كه جنبه هاى مثبت را كم ارزش جلوه مى دهند. اين بيماران در حين فعال شدن اين طرح واره، معمولاً دست به بيش بينى هاى افراطى مى زنند. مثلا بيش بينى 


$$
\text { تعميم نتايج به ديخر استان ها احتياط شوده استان قم باشد كه واجب است، در }
$$

سباسگز ارى

از اساتيد محترم، مراكز مشاوه و شركت كت كند گان كه در اين يُزوهش همكارى داشتند، سياسگز ارى مى شود.

\section{References}

Bahramizadeh H, Bahrami Ehsan H. (2013). Interrelations between early maladaptive schema and personality traits. J Res Behav Sci, 11(3),219-227 (In persian).

Besharat MA, Karimy K, Rahiminejad A. (2006). The studying of relationship between attachment style and personality phase. J psychology \& cultural science, 36(1\&2),3755 (In persian).

Calvete E, Orue L, Hankin BL. (2013). Early maladaptive schemas and social anxiety in adolescents: The mediating role of anxious automatic thoughts. J Anxiety Disord, 27(3),278-288.

Damiano SR, Reece J, Reid S, Atkins L, Patton G. (2015). Maladaptive schemas in adolescent females with norexia nervosa and implications for treatment. Journal of Eat behave, 16(4),64-71.

Deniz M E, Hamarta E, An R. (2005). An investigation of social skills and loneliness levels of university students with respect to their attachment styles in a sample of Turkish students, Social Behavior and Personality, 33 (1),19-32.

Dilmaç B, Hamarta E, Arslan C. (2009). Analyzing the trait anxiety and locus of control of undergraduates in terms of attachment styles. Journal of Educational Sciences: Theory \& Practice, 9 (1),127-159.

Fata L, Mootabi F, Dobson K, Moludi R, Zeaee K. (2010). Psychometric Properties of Young Schema Questionnaire in an Iranian Nonclinical Sample. Journal of Management System University of Tabriz, 16(4),227-246 (In persian).
نوزار - مادر شكل مى گيرد و در مراحل بعدى تحول

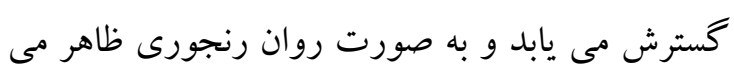

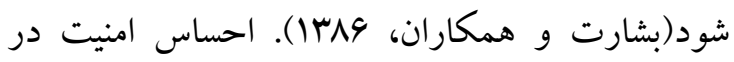
افراد با دلبستگى ايمن باعث مى شود كه فرد ثبات

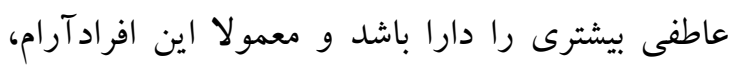
معتدل و راحت هستند. اين ويثز دلبستكى ايمن با ويزگى هاى افرادى كه در روان

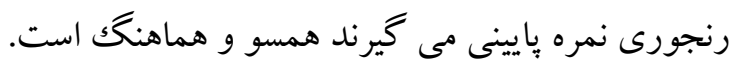

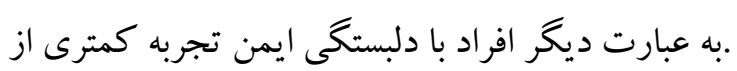
عواطف منفى جون ترس، غم، اضطراب، عصبانيت، احساس كناه و نفرت دارند و در نتيجه در روان

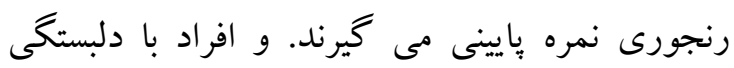
دوسو گرا تجربه هر جه بيشترى اين عواطف دئ دارند و در نتيجه در روان رنجورى نمرات بالاترى دريافت مى

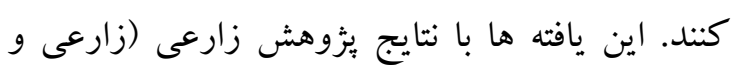

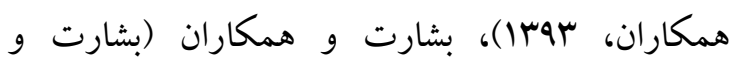
همكارن، هAץ|)، دنيز و همكاران (دنيز و همكاران، ه.(Y)، ديلماس و همكاران (ديلماس و همكاران،

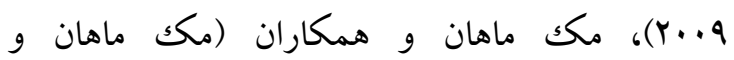

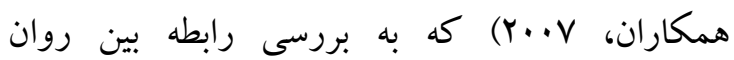
رنجورى و دلبستخى توجه كرده اند، مطابقت دارد.

\section{نتيجه كيرى}

نتايج يافته هاى اين ئزوهش در زمينه اين كه از بين

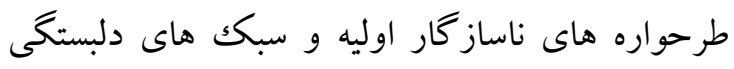
كدام عامل براى بيش بينى روان رنجورى از اولويت بيشترى برخوردار است، نشان داد كه مهمترين عامل براى ييش بينى روان رنجورى به ترتيب طرح واره عدم

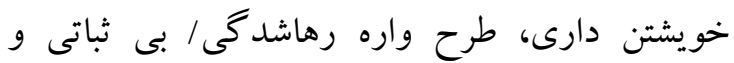

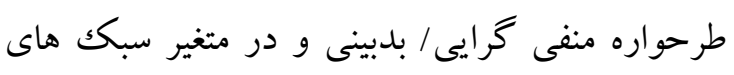

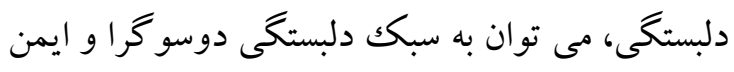

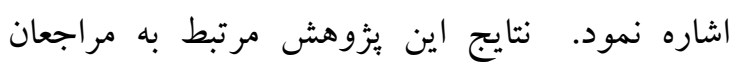


Garousi Farashi MT. (1380). Personality evaluation. first ed. Tabriz: Nashre Danial \& jame pazhoh, (In persian).

Mason O, Platts H, Tyson M. (2005). Early maladaptive schemas and adult attachment In a UK clinical population. Joumal of Psychol Psychother, 78(4),549-64.

McCrae RRR, Costa. (1991). Adding liebe underbeit: The Full Five-factor model of well-being. Prersonality \& social psychology bulletin.

McMahon B. (2007). Organizational commitment, relationship commitment and their association with attachment style and locus of control. Unpublished master's thesis, Master of Science in Psychology, Georgia Institute of Technology, Atlanta.

Muris P. (2006). Maladaptive schemas in non-clinical adolescents: relations to perceived parental rearing behaviours, big five personality factors and psychopathological symptoms. Journal of Clinical Psychology and Psychotherapy, 13(1),405-413.

Noeiiran L, Mahmoud Alilou M. (2015). Predictingquality of lifeand happinessbased onattachment style. Iranian Joumal of Rehabilitation Research in Nursing, 1(4),6069 (In persian).

Rezaei M, GHolamrezayi S, Sepahvandi M, Ghazanfari F, Darikvand F. (2013). The potency of early maladaptive schemas and personality dimensions in prediction of depression. Thought and Behavior in Clinical Psychology, 8(29),77-86 (In persian).

Sava FA. (2009). Maladaptive schemas, irrational beliefs, and their relationship with the fivefactor personality model. Joumal of Cognitive and Behavioral Psychotherapies,9(5), 135-147.

Tabachnick BG, Fidell LS. (2007). Using Multivariate Statistics. Boston: Pearson/ Allyn \& Bacon.

Thimm JC. (2010). Personality and early maladaptive schemas: A five-factor model perspective. Journal of behavior therapy and experimental psychiatry, 41(4), 373-380.

Wang CE, Halvorsen M, Eisemann M, Waterloo K. (2010). Stability of dysfunctional attitudes and early maladaptive schemas: A 9-year follow-up study of clinically depressed subjects. Joumal of Behavior Therapy and Experimental Psychiatry, 41(4), 389-396.

Young JE, Klosko JS, Weishaar ME. (2003). Schema therapy, A practitioner's guide. New York: Guilford Press.

Young JE. (1991). Cognitive therapy for personality disorders a schema focused approach (Practitioner's Resource Series).3 rd.ed. US: Professional Resource Exchange.

Zarei E, Karami Boldaji R, Heydari H, Hossein Khanzadeh A, Baharloo G. (2014). Prediction of the Five-Factor Personality Traits of Students based on Adult Attachment Styles. J Resaerch of cognitive and Behavioral Sciences, 1(4),167-180 (In persian). 